\title{
Review Article \\ Immune Responses Associated with Resistance to Haemonchosis in Sheep
}

\author{
Fernando Alba-Hurtado and Marco Antonio Muñoz-Guzmán \\ Departamento de Ciencias Biológicas, Facultad de Estudios Superiores Cuautitlán, \\ Universidad Nacional Autónoma de México, Km. 2.5 Carretera Cuautitlán-Teoloyucan, 54714 Cuautilán Izcalli, MEX, Mexico \\ Correspondence should be addressed to Fernando Alba-Hurtado; fealba@hotmail.com
}

Received 18 July 2012; Revised 19 September 2012; Accepted 28 September 2012

Academic Editor: Luis I. Terrazas

Copyright (C) 2013 F. Alba-Hurtado and M. A. Muñoz-Guzmán. This is an open access article distributed under the Creative Commons Attribution License, which permits unrestricted use, distribution, and reproduction in any medium, provided the original work is properly cited.

\begin{abstract}
This paper examines the known immunological and genetic factors associated with sheep resistance to infection by Haemonchus contortus. Such resistance is an inheritable genetic trait $\left(h^{2}, 0.22-0.63\right)$ associated with certain sheep breeds. Resistant sheep do not completely reject the disease; they only harbor fewer parasites than susceptible sheep and therefore have a lower fecal egg count. Protective immune response to haemonchosis is an expression of genetic resistance. Genes associated with resistance and susceptibility are described. Genetically resistant sheep have nonspecific mechanisms that block the initial colonization by Haemonchus contortus larvae. These sheep also have an efficacious Th2 type response (e.g., increases in blood and tissue eosinophils, specific IgE class antibodies, mast cells, IL-5, IL-13, and TNF $\alpha$ ) that protects them against the infection; in contrast, susceptible sheep do not efficiently establish this type of immune response. Finally, the main reported antigens of $H$. contortus were reviewed.
\end{abstract}

\section{Introduction}

Gastroenteric verminosis is a disease with a great economic impact on sheep farms located in humid areas including tropical and subtropical regions of the world [1]. In Australia, losses due to this disease have been estimated at more than 400 million dollars (USD) per year; treatments in Kenya, South Africa, and India cost up to 26, 46, and 103 million USD, respectively [2]. Due to its ubiquity and virulence, Haemonchus contortus is the most important gastroenteric nematode of sheep in many regions of the world. It is a blood-sucking parasite of the abomasum that causes a disease known as haemonchosis $[3,4]$.

Haemonchosis is acquired by ingesting pasture contaminated with the third stage larvae (L3) of H. contortus. L3 penetrates the abomasal glands, where they molt into L4. The presence of larvae induces abomasal gland hyperplasia, inflammatory cell infiltration, and the substitution of wall cells secreting $\mathrm{HCl}$ with young nonsecreting cells. Consequently, the abomasal $\mathrm{pH}$ increases, which in turn reduces the transformation of pepsinogen to pepsin, reduces protein digestion, increases mucosa permeability, and increases the loss of endogenous proteins in the abomasum. Adult parasites are found in the abomasum lumen, and they are voracious hematophagous parasites, daily consuming $0.05 \mathrm{~mL}$ of host blood per worm [5]. The negative effects of haemonchosis on the biological and economic efficiency of sheep herds include malnutrition, low feed conversion, anemia, loss of appetite, low fertility indices, and in certain cases the death of young animals $[3,6]$.

Parasite control is based almost entirely on the administration of anthelmintic chemical compounds. Unfortunately, one of the problems generated by the massive, and indiscriminate use of anthelmintic products is the increasing resistance to these drugs, and this situation has huge consequences in those countries where sheep production is one of the main economic activities [7-9]. Together with the anthelmintic resistance problem, there is a trend toward the reduction of drug residues in human food and in the environment, which mandates that antiparasitic control strategies must not depend on chemicals. Among some of the proposed strategies are the development of specific vaccines against gastroenteric nematodes and the use of animal genotypes that are resistant to parasite infections. 


\section{Resistance and Resilience}

Nematode resistance includes the initiation and maintenance of a host response that prevents, reduces, or clears parasitic infection $[10,11]$. Resistant animals do not completely reject the disease, but they have a lower parasitic load than susceptible animals, as measured by fewer eggs in their feces. This resistance is based on the immunological capabilities of each individual when challenged with parasitoses [12].

Resilience is the capacity of an animal to compensate for the negative effects of parasitism by the maintenance of productive parameters [13]. Sheep in general show simultaneously high resistance and resilience to haemonchosis. Some breeds have moderate or low resistance with relatively high resilience, allowing them to have productivity similar to those that are naturally resistant [14].

\section{Breeds Susceptible and Resistant to Haemonchosis}

Differences between sheep breeds in their susceptibility to infection by abomasum-inhabiting nematodes were first reported by Stewart et al. [15], who described higher resistance to Ostertagia circumcincta (currently Teladorsagia circumcincta) in Romney Marsh lambs compared with lambs of the Rambouillet, Shropshire, Southdown, and Hampshire breeds and their crosses. Ross et al. [16] reported the first evidence for heritable resistance to haemonchosis in sheep. Subsequently, it has been shown that some sheep breeds are more resistant to gastroenteric nematodes than others. Table 1 lists selected comparisons between breeds and the parameters of susceptibility or resistance that were measured. Additionally, there are individual differences within breeds [17].

The resistance of some breeds can be explained by their place of origin. In general, resistant breeds were selected from areas where the climate favors the growth of gastroenteric nematode larvae in the environment, such that selection for certain productive parameters over several generations affected an indirect selection for nematode resistance. In fact, native breeds that have prospered despite unfavorable environmental conditions, poor zootechnical management, and no anthelmintic treatments are more resistant than highly productive breeds selected in areas with optimal health and zootechnical management [14].

There are several ways to assess genetic resistance to gastroenteric nematodes. The most common method is the fecal egg count (FEC), which has intrinsic limitations because the number of eggs in feces is not necessarily correlated with the host's parasite load [18]. Low or reduced FEC has been used as a parameter for sheep selection in Australia $[19,20]$ and New Zealand [21]. The most trusted method to measure a sheep breed's resistance to gastroenteric nematodes is to count the total parasites (larvae and adults) in the gastrointestinal tract of the assessed sheep. Because this method can only be performed at necropsy, it is not useful for the genetic selection of sheep $[10,22]$.

The use of haemonchosis-resistant sheep breeds has been proposed as a way to control the spread of drug-resistant strains of $H$. contortus. However, many of these breeds do not have the productive indices of other breeds; instead, some researchers are trying to select sheep for high resistance from productive breeds such as Merino and Romney, this resistance is a characteristic that is inherited by their descendants $[19,20]$. The hereditability $\left(h^{2}\right)$ of FEC varies between 0.22 and 0.63 , indicating that selection for resistance or against susceptibility using this parameter can be moderately useful $[23,24]$. Genetic markers associated with resistance could also be used to select sheep within a breed. There are many ongoing studies of resistance-associated genetic markers and some preliminary results. Alleles OMHC1-188 and OLADRB2-282 of the major histocompatibility complex (MHC) [25] and several quantitative trait loci (QTL) that contain diverse significant loci, such as the IFN $\gamma$ locus in chromosome $3[26,27]$, have been associated with FEC reduction. Furthermore, some genes associated with the early inflammatory response including those encoding toll-like receptors (TLR2, 4 and 9) or involved with free radical production (DUOX1 and NOS2 A) are more abundantly expressed in lambs that are resistant to $H$. contortus and Trichostrongylus colubriformis infections [28].

\section{Immune Response in Ovine Haemonchosis}

The immunological mechanisms by which sheep have or acquire resistance to haemonchosis are not very clear $[50,53]$; this resistance is an individual characteristic that has been associated with age, breed, and previous exposure to the parasite (infection or reinfection).

Both innate and adaptive immunities protect the host from $H$. contortus infection. Clearance of the nematode in immunized sheep requires several events, including the activation of nonspecific defense mechanisms, the recognition of parasitic somatic and excretion/secretion antigens, and the initiation of an appropriate acquired response [54].

4.1. Nonspecific Response Mechanisms to Haemonchosis. $H$. contortus larvae must inhabit an appropriate gastrointestinal niche that nourishes their development and growth and protects them from mechanical (peristaltic movement) and chemical (abomasum mucus) host barriers. Parasite colonization of the host abomasum initially depends on the motility of the larvae and the parasite load. Some host individuals, after sensitization via previous infections, can modify the microenvironmental conditions of the niche to expel the parasite [55].

Complement fixation is one of the first innate responses to $H$. contortus infection. Several studies demonstrated that helminths activate the alternate complement pathway and bind some molecules (opsonins) on their surface [56]. After larvae activate complement, vasoactive and chemotactic peptides ( $\mathrm{C} 3 \mathrm{a}$ and $\mathrm{C} 5 \mathrm{a}$ ) are generated, and these peptides mobilize eosinophils to the area of infection independently of specific mechanisms (CD4+ and IL-5). At the same time, $H$. contortus secretes chemoattractants for eosinophils and neutrophils, which reinforce the inflammatory response [57]. The thymus-independent increase in tissue eosinophils is an 


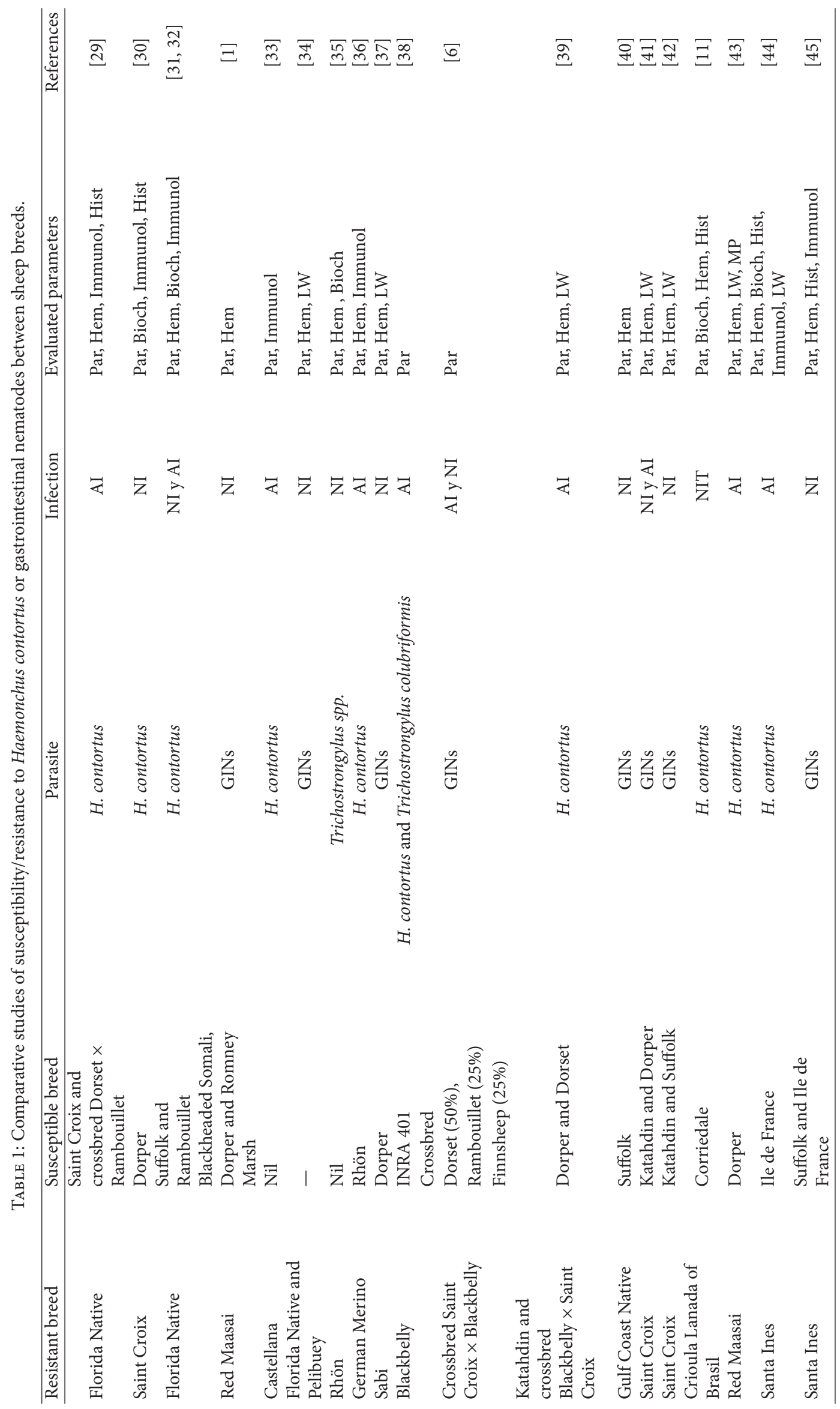




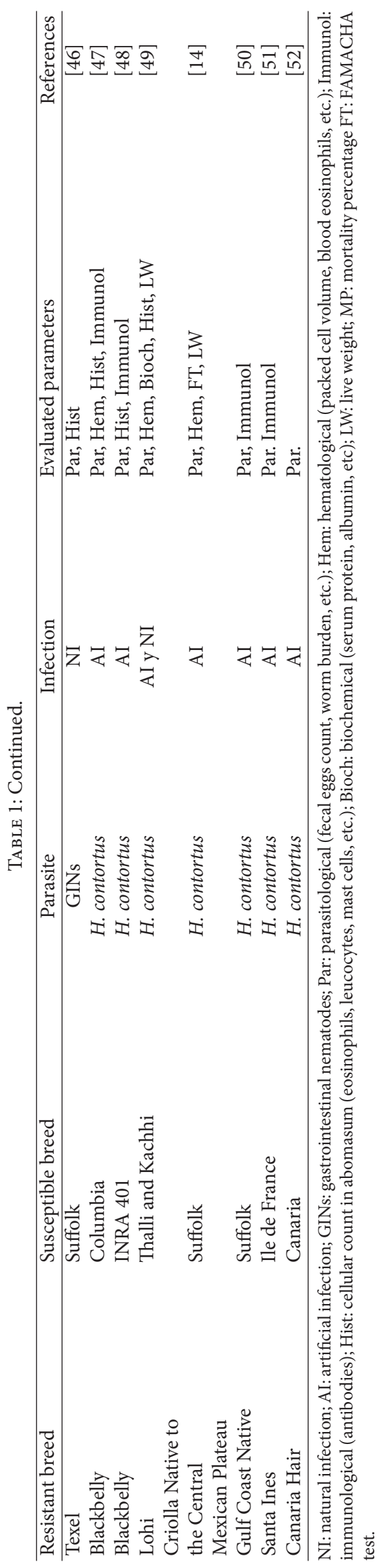


important innate response in which complement activation mediates the cytotoxicity of eosinophils against larvae in early infection stages in the absence of specific antibodies.

When rodents are used as experimental models for gastrointestinal helminths, the quick elimination of parasites during the first infection is associated with inflammation induced by the alternate complement pathway and mediated by mast cells and eosinophils [56]. In contrast to rodent models, efficient elimination of nematode larvae in ruminants generally requires repeated infections [58].

Expulsion of $H$. contortus larvae in sheep can be immediate or delayed. Immediate expulsion occurs when larvae are attacked by tissue mast cells and a special type of intraepithelial mast cells (globule leucocytes) before the larvae enter their niche (abomasum gland). Similar to murine experimental models, other important mechanisms in the immediate expulsion from sheep are hypermotility, gastric hypersecretion, and hyperplasia of calciform cells with the subsequent increase in mucus production $[55,58]$. These mechanisms may explain why some sheep breeds or genetically resistant genotypes counteract infection during its early stages.

MacKinnon et al. [59] found that resistant and susceptible sheep breeds exhibited differential gene expression that was associated with an nonspecific response to $H$. contortus. At 3 days after infection (PI) with $H$. contortus, resistant sheep had reduced expression of genes associated with blood coagulation and higher expression of genes involved in the inhibition of coagulants, tissue repair and restructuring, blood vessel formation, and cell migration in the abomasum and abomasal lymph node. At day 27 PI, resistant sheep had higher expression of genes associated with intestinal motility, inflammatory response, cell differentiation and proliferation, and the reduction of apoptosis.

Ghrelin is a growth hormone peptide ( 28 amino acids) of the stomach and is the endogenous ligand for GH secretagogue receptor [60]. It also stimulates appetite, regulates homeostasis of energy metabolism, and contributes to the modulation of the inflammatory response [61, 62]. Experimental infection with $H$. contortus in susceptible lambs reduces the expression of the ghrelin gene in abomasum and decreases the protein in plasma; in contrast, ghrelin gene expression and protein plasma content increase in resistant lambs [63]. Ghrelin reduction is most likely associated with appetite suppression and downregulation of the prolonged inflammatory response in susceptible lambs.

Immediate expulsion of the parasite is also associated with the presence of histamine and leukotrienes in the abomasum mucus, which inhibit the motility of nematode larvae in vitro. When challenged with the parasite, sheep immunized with $H$. contortus or Trichostrongylus colubriformis have a higher number of mast cells and globule leukocytes in the abomasum mucosa, and these cells have higher secretion of leukotrienes and factors that inhibit larvae migration [64]. High concentrations of histamine in the abomasal mucosa of sheep that are resistant to haemonchosis aid parasite expulsion by promoting abomasal hypersecretion and hypermotility, which are detrimental to the fecundity and motility of the worm [65]. Furthermore, histamine facilitates the translocation of plasma proteins including humoral antibodies into the lumen of the abomasum [55].

Delayed expulsion of $H$. contortus larvae occurs when a specific immune response is mounted against the larvae in the abomasum glands. This action is regulated by CD4+ $\mathrm{T}$ lymphocytes, IgA and IgE antibodies, antibody-dependent eosinophil cytotoxicity, and the classic complement pathway [58].

Tissue and blood eosinophils are increased during both the specific and nonspecific responses against gastrointestinal nematodes. The activation of the alternate pathway and degranulation of mast cells cause the increase and nonspecific degranulation of tissue eosinophils which is independent of IL-5. In addition to recruiting eosinophils to the abomasum wall, complement promotes eosinophil cytotoxicity against $H$. contortus larvae [66]. Infection with Oestrus ovis or inoculation with Taenia hydatigena larvae extracts induces eosinophilia in the abomasum and promotes resistance to haemonchosis in sheep $[67,68]$.

Eosinophil degranulation releases major basic protein, cationic proteins, and peroxidase, which are cytotoxic to helminths. Lipid mediators such as leukotrienes, prostaglandin E2, platelet aggregation factor, and lipoxins are secreted, and these molecules promote increases in permeability, mucus secretion, chemotaxis, and coagulation. Eosinophils also produce cytokines IL4 and IL10, suggesting that these cells have a regulatory function in the immune response [69].

The exact role of $\gamma \delta \mathrm{T}$ lymphocytes is unclear. These cells have been associated with resistance to haemonchosis $[4,70]$, but it is unknown whether they are involved in resistance and/or immunity or if their presence is only a secondary effect $H$. contortus infection.

4.2. H. contortus Antigens. During the infection of sheep, $H$. contortus progresses through various life cycle stages (L3, L4, L5, and adult), among which there are differences in surface molecule expression. Some antigens specific to L3 and L4 are not expressed during the adult stage [71]. Quick changes in surface antigens make an effective adaptive response difficult in the initial stages of infection; therefore, each developmental stage is immunologically a different organism [54]. Thus, the larval antibody response does not cross-react with the adult stage.

Hidden antigens from the $H$. contortus intestine have been used to elicit a Th2-type response and the production of host serum antibodies, which are subsequently ingested when nematodes feed on the host's blood. The ingested antibodies recognize the nematode's intestinal antigens and alter its digestion [72]. The best-characterized and most effective intestinal antigens are the enzyme complexes $\mathrm{H} 11$ and $\mathrm{H}$ gal-GP. The first is a family of microsomal aminopeptidases, and the latter is an aspartyl protease and metalloprotease complex. Together, these antigens, which have been obtained directly from adult worms, provide substantial protection against natural infection by $H$. contortus in sheep [73-75]. Immunization with $\mathrm{H}$-gal-GP results in the production of host antibodies that inhibit the hemoglobinase activity of the endogenous enzyme, leading to $H$. contortus malnutrition 
due to decreased blood digestion [76]. However, the induced protection is short lived, and the difficulties of large-scale production of immunogens limit their commercial development. Sheep immunized with the same recombinant antigens expressed in Escherichia coli and insect intestinal cells have been unsuccessful to be protected from infection $[75,77]$.

Other antigens have been evaluated as immunogens. Molina et al. [78] showed that immunization with cysteine protease-enriched protein fractions obtained from adult $H$. contortus worms protected sheep and goats against experimental infection with the parasite. The $70-83 \mathrm{kDa}$ surface antigens obtained from exsheathed larvae, and the 15 and $24 \mathrm{kDa}$ excretion/secretion antigens produce some degree of protection $[79,80]$. Infection with different nematodes induces the abomasal and intestinal production of IgG antibodies against a carbohydrate larval antigen (CarLA) present on the surface of various strongylid nematodes. Incubation of exsheathed Trichostrongylus colubriformis larvae with these antibodies inhibited their implantation in the small intestine. However, the incubation of exsheathed $H$. contortus larvae with these antibodies did not have an effect on their implantation in abomasum [81].

Haemonchosis resistance has been associated with alleles of the ovine MHC (OMHC1-188) and with certain surface molecules of ovine leukocytes (OLADRB2-282), suggesting that the mechanisms of antigen presentation differ between breeds $[25,82]$. Some dendritic cells can internalize antigens homologous to those of $H$. contortus [83], so the specific response to $H$. contortus may be induced by the dendritic cell-mediated presentation of parasite antigens to helper $\mathrm{T}$ lymphocytes. Eosinophils also function as antigen-presenting cells, particularly in the case of helminthic infections. Eosinophils exposed to Strongyloides stercoralis antigens had increased expression of CD69, CD86, and MHC class II similar to dendritic cell controls, these eosinophils transformed in vitro naïve CD4+ lymphocytes to IL-5-producing CD4+ Th2 cells [84].

4.3. Antibodies and Resistance to Haemonchosis. Natural and experimental infections with $H$. contortus induce the production of specific antibodies. The serum antibody response has been widely studied although results have been variable. While some studies show an association between serum IgG levels and resistance [47], others found an association with infection but not with resistance [33, 45]. Abomasum antibodies are more important than serum antibodies in the protection against gastroenteric nematodes. High specific IgA levels in the abomasal mucus decrease the fertility and length of Teladorsagia circumcincta, which is another abomasum nematode of sheep [85]. There is a negative correlation between the amount of specific IgA in abomasum mucus and the parasite burden in H. contortus infections [45].

A typical characteristic of helminthic infections is the induction of specific IgE, which results from a Th2-type response. IgE induces antibody-dependent cytotoxicity in eosinophils, mast cells, and macrophages. An increase in local IgE levels has been associated with resistance to gastroenteric nematodes in sheep and goats [86-88]. In in vitro assays, this immunoglobulin recognizes nematode surface allergens and directs eosinophils and mast cells to attack the parasite cuticle [48]. These functions are mediated by a high affinity IgE receptor present on the surface of these cells (FceRI). A surface epitope of $H$. contortus has a $\alpha 1 \rightarrow 3$-fuc domain that is recognized by IgE. This epitope was previously found in other helminths, plants, and some arthropods, and it has been associated with the induction of Th2-type responses and allergic processes [89].

Infection produces an increase in antibody-producing plasma cells, mainly of the IgA isotype [90]. Because the number of these cells is similar in susceptible and resistant sheep breeds experimentally infected with $H$. contortus, they have not been associated with resistance [91]. Activated B lymphocytes $(\mathrm{CD} 45 \mathrm{R}+)$ are also increased during $H$. contortus infection $[4,58]$.

4.4. Immune Response Cells Associated with Resistance. Inoculation with $H$. contortus larvae induces $\mathrm{T}$ lymphocyte proliferation and the subsequent enlargement of abomasal lymph nodes and an increase in CD4+ lymphocytes in the abomasum wall and peripheral blood [70, 92, 93].

In experimental infections, CD4+ lymphocytes are required for inducing immunity in ovine haemonchosis. Neutralization of CD4+ lymphocytes by monoclonal antibodies negates $H$. contortus immunity and increases the parasite burden in sheep resistant to infection. This neutralization also suppresses mucosa mast cell hyperplasia, eosinophil infiltration of the abomasum, and the development of humoral memory response [94-96]. In contrast, the presence or absence of CD8+ lymphocytes seems to have no effect on resistance $[58,91]$.

Depending on the activation stimulus, murine helper CD4+ T lymphocytes differentiate into two cell types with different cytokine production profiles. Type $1 \mathrm{~T}$ lymphocytes (Th1), characterized by the production of IFN $\gamma$ and IL-2 among others, constitute the cellular response and protect against intracellular parasites such as Leishmania sp. and Toxoplasma gondii. The Type 2 response (Th2), characterized by the production of IL-4, IL-5, and IL-10, is part of the humoral response and associated with the presence of helminths. The Th1 and Th2 responses are antagonistic to each other. The Th1 response inhibits the Th2 response through IL-10 [97]. The polarization of the Th1-Th2 response observed in mice and humans has not been demonstrated in ruminants, but it has been possible to establish the existence of a differentiated response associated with IL-5, eosinophils, mast cells, IgG1, and IgE in sheep resistant to haemonchosis [98]. There is also evidence that effector mechanisms of the Th2 type response are involved in immunity against $H$. contortus [50, 91].

It appears that susceptibility and resistance to haemonchosis depend on the type of immune response mounted against the parasite. CD4+ lymphocytes increase during experimental infection of both susceptible and resistant sheep. Thus, both groups respond to the presence of the parasite but do so in different manners. Compared with resistant sheep, susceptible sheep produce relatively more IFN $\gamma$ and less parasite-specific serum antibodies, blood eosinophils, and abomasum eosinophils [98]; therefore susceptibility is 
most likely associated with a Th1 type response [47, 50], while resistance includes a Th2 type response. A differential response has also been observed in different abomasum regions. Muñoz-Guzmán et al. [91] found that resistant lambs experimentally infected with $H$. contortus had a Th2 type response (increase of eosinophils and CD4+ lymphocytes) in their abomasal pyloric region, and this response was not observed in the fundus region of the same lambs or in any abomasal regions of susceptible lambs.

Other studies suggest that there is a Th1/Th2 dichotomy in sheep infected with gastroenteric nematodes. Gill et al. [98] studied the levels of IFN $\gamma$ and IL-5 produced in vitro by abomasum lymphocytes stimulated with $H$. contortus antigens. Lymphocytes obtained from uninfected resistant sheep produced quantities of each cytokine similar to susceptible sheep, but lymphocytes obtained from infected resistant sheep produced less IFN $\gamma$ and more IL-5 than lymphocytes obtained from susceptible sheep. These studies indicate that protection is mainly due to a Th2-type response.

Genetic studies confirm the aforementioned observations. Pernthaner et al. [99] showed that resistant sheep expresss the genes for IL-5, IL-13, and TNF $\alpha$ and do not express those of IL-4, IL-10, and IFN $\gamma$. Andronicos et al. [100] showed that, after the initial infection, there were no differences in cxcl10 gene (regulator of IFN $\gamma$ ) expression in the abomasum mucosa of lambs susceptible and resistant to haemonchosis. In subsequent infections susceptible lambs overexpressed this gene, which most likely made them incapable of establishing a protective Th2-type response. A similar effect was reported in mice, where overexpression of cxcl10 decreased clearance of Trichuris muris infection in susceptible mice [101].

An essential factor modulating the type of response is the age at the time of infection. Lambs that are three to six months old have fewer CD4+ lymphocytes in the abomasum wall related to diminished immune response against $H$. contortus [102]. In contrast, a greater number of $\gamma \delta$ T lymphocytes have been observed in the abomasum wall of young sheep [103]. Bovine $\gamma \delta \mathrm{T}$ lymphocytes stimulated with concanavalin $\mathrm{A}$ produced IL-2, IFN $\gamma$, and TNF $\alpha$ [104]. If the same pattern of cytokines is produced by $\gamma \delta \mathrm{T}$ lymphocytes of young sheep, they would mount Th1 type response. While this hypothesis could explain the high susceptibility of young lambs to infection, it requires the support of further studies.

In the first infection with $H$. contortus, the abomasum lymphocytes of susceptible sheep breeds do not produce cytokines associated with a Th2 response, but, in later infections, the production of these cytokines increases [58]. While these sheep do not reach the levels of resistance of genetically resistant sheep, the increased production of Th2 cytokines could contribute to the increased resistance to $H$. contortus in adult sheep of susceptible breeds.

\section{Conclusions}

Resistance to haemonchosis is an inheritable genetic characteristic associated with some sheep breeds. The immune response that protects against $H$. contortus is the expression of this genetic resistance. Genetically resistant sheep have innate defense mechanisms that prevent their colonization by larvae during their first infection. Additionally, they establish a Th2 type immune response in the abomasum mucosa that protects them from infection, but susceptible sheep do not efficiently establish this type of immune response. Finally, the immune response and the associated resistance can be modified by the type of antigen that is recognized and by such factors as age, nutrition, and the number of infections.

\section{Acknowledgments}

This work was conducted as a part of the Projects PAPIIT/UNAM nos. IT223311, IT223011 and Cátedra: Epidemiología de las Enfermedades Parasitarias of FESCUNAM-2012.

\section{References}

[1] J. M. Mugambi, R. K. Bain, S. W. Wanyangu et al., "Resistance of four sheep breeds to natural and subsequent artificial Haemonchus contortus infection," Veterinary Parasitology, vol. 69, no. 3-4, pp. 265-273, 1997.

[2] D. Sackett, P. H. Holmes, K. Abbott, S. Jephcott, and M. Barber, "Assessing the economic cost of endemic disease on the profitability of Australian beef cattle and sheep producers," AHW.087 Report, Meat and Livestock Australia, North Sydney, 119, 2006.

[3] R. H. Quiroz, "Parasitología y enfermedades parasitarias de los animales domésticos," Limusa, México D.F., México, 1984.

[4] A. Balic, V. M. Bowles, and E. N. T. Meeusen, "The immunobiology of gastrointestinal nematode infections in ruminants," Advances in Parasitology, vol. 45, pp. 181-241, 2000.

[5] M. Cordero del Campillo, F. A. Rojo Vazquez, A. R. Martínez Fernandez et al., Parasitología Veterinaria, McGraw-Hill, Madrid, España, 1999.

[6] D. R. Notter, S. A. Andrew, and A. M. Zajac, "Responses of hair and wool sheep to a single fixed dose of infective larvae of Haemonchus contortus," Small Ruminant Research, vol. 47, no. 3, pp. 221-225, 2003.

[7] J. A. Van Wyk, M. O. Stenson, J. S. Van der Merwe, R. J. Vorster, and P. G. Viljoen, "Anthelmintic resistance in South Africa: surveys indicate an extremely serious situation in sheep and goat farming," Onderstepoort Journal of Veterinary Research, vol. 66, no. 4, pp. 273-284, 1999.

[8] M. Saeed, Z. Iqbal, A. Jabbar et al., "Multiple anthelmintic resistance and the possible contributory factors in Beetal goats in an irrigated area (Pakistan)," Research in Veterinary Science, vol. 88, no. 2, pp. 267-272, 2010.

[9] A. S. Cezar, G. Toscan, G. Camillo, L. A. Sangioni, H. O. Ribas, and F. S. F. Vogel, "Multiple resistance of gastrointestinal nematodes to nine different drugs in a sheep flock in southern Brazil," Veterinary Parasitology, vol. 173, no. 1-2, pp. 157-160, 2010.

[10] V. Hooda, C. L. Yadav, S. S. Chaudhri, and B. S. Rajpurohit, "Variation in resistance to haemonchosis: selection of female sheep resistant to Haemonchus contortus," Journal of Helminthology, vol. 73, no. 2, pp. 137-142, 1999.

[11] P. A. Bricarello, S. M. Gennari, T. C. G. Oliveira-Sequeira, C. M. S. L. Vaz, I. Gonçalves De Gonçalves, and F. A. M. Echevarria, 
"Worm burden and immunological responses in Corriedale and Crioula Lanada sheep following natural infection with Haemonchus contortus," Small Ruminant Research, vol. 51, no. 1, pp. 75-83, 2004.

[12] H. S. Gill, "Genetic control of acquired resistance to haemonchosis in Merino lambs," Parasite Immunology, vol. 13, no. 6, pp. 617-628, 1991.

[13] V. Paolini, F. De La Farge, F. Prevot, P. Dorchies, and H. Hoste, "Effects of the repeated distribution of sainfoin hay on the resistance and the resilience of goats naturally infected with gastrointestinal nematodes," Veterinary Parasitology, vol. 127, no. 3-4, pp. 277-283, 2005.

[14] F. Alba-Hurtado, E. Romero-Escobedo, M. A. Muñoz-Guzmán, G. Torres-Hernández, and C. M. Becerril-Pérez, "Comparison of parasitological and productive traits of Criollo lambs native to the central Mexican Plateau and Suffolk lambs experimentally infected with Haemonchus contortus," Veterinary Parasitology, vol. 172, no. 3-4, pp. 277-282, 2010.

[15] M. A. Stewart, R. F. Miller, and J. R. Douglas, "Resistance of sheep of different breeds to infestation by Ostertagia circumcincta," Journal of Agricultural Research, vol. 55, pp. 923-930, 1937.

[16] J. G. Ross, R. P. Lee, and J. Armour, "Haemonchosis in Nigerian Zebu cattle: the influence of genetical factors in resistance," Veterinary Record, vol. 71, pp. 27-31, 1959.

[17] T. Sréter, T. Kassai, and E. Takács, "The heritability and specificity of responsiveness to infection with Haemonchus contortus in sheep," International Journal for Parasitology, vol. 24, no. 6, pp. 871-876, 1994.

[18] M. J. Stear and M. Murray, "Genetic resistance to parasitic disease: particularly of resistance in ruminants to gastrointestinal nematodes," Veterinary Parasitology, vol. 54, no. 1-3, pp. 161-176, 1994.

[19] R. R. Woolaston, "Factors affecting the prevalence and severity of footrot in a merino flock selected for resistance to Haemonchus contortus," Australian Veterinary Journal, vol. 70, no. 10, pp. 365-369, 1993.

[20] S. J. Eady, R. R. Woolaston, S. I. Mortimer et al., "Resistance to nematode parasites in Merino sheep: sources of genetic variation," Australian Journal of Agriculture Research, vol. 47, no. 6, pp. 895-915, 1996.

[21] A. Pernthaner, M. Stankiewicz, S. A. Bisset, W. E. Jonas, W. Cabaj, and H. D. Pulford, "The immune responsiveness of Romney sheep selected for resistance or susceptibility to gastrointestinal nematodes: lymphocyte blastogenic activity, eosinophilia and total white blood cell counts," International Journal for Parasitology, vol. 25, no. 4, pp. 523-529, 1995.

[22] A. Pfeffer, P. G. C. Douch, R. J. Shaw et al., "Sequential cellular and humoral responses in the abomasal mucosa and blood of Romney sheep dosed with Trichostrongylus axei," International Journal for Parasitology, vol. 26, no. 7, pp. 765-773, 1996.

[23] R. G. Windon, "Genetic control of resistance to helminths in sheep," Veterinary Immunology and Immunopathology, vol. 54, no. 1-4, pp. 245-254, 1996.

[24] J. E. Miller and D. W. Horohov, "Immunological aspects of nematode parasite control in sheep," Journal of Animal Science, vol. 84, no. 13, pp. 124-132, 2006.

[25] J. A. Figueroa Castillo, R. D. M. Medina, J. M. B. Villalobos et al., "Association between major histocompatibility complex microsatellites, fecal egg count, blood packed cell volume and blood eosinophilia in Pelibuey sheep infected with
Haemonchus contortus," Veterinary Parasitology, vol. 177, no. 34, pp. 339-344, 2011.

[26] K. Marshall, J. F. Maddox, S. H. Lee et al., "Genetic mapping of quantitative trait loci for resistance to Haemonchus contortus in sheep," Animal Genetics, vol. 40, no. 3, pp. 262-272, 2009.

[27] S. Dominik, "Quantitative trait loci for internal nematode resistance in sheep: a review," Genetics Selection Evolution, vol. 37, supplement 1, pp. S83-S96, 2005.

[28] A. Ingham, A. Reverter, R. Windon, P. Hunt, and M. Menzies, "Gastrointestinal nematode challenge induces some conserved gene expression changes in the gut mucosa of genetically resistant sheep," International Journal for Parasitology, vol. 38, no. 3-4, pp. 431-442, 2008.

[29] A. M. Zajac, S. Krakowka, R. P. Herd, and K. E. McClure, "Experimental Haemonchus contortus infection in three breeds of sheep," Veterinary Parasitology, vol. 36, no. 3-4, pp. 221-235, 1990.

[30] H. R. Gamble and A. M. Zajac, "Resistance of St. Croix lambs to Haemonchus contortus in experimentally and naturally acquired infections," Veterinary Parasitology, vol. 41, no. 3-4, pp. 211-225, 1992.

[31] R. E. Bradley, C. V. Radhakrishnan, V. G. Patil Kulkarni, and P. E. Loggins, "Responses in Florida native and Rambouillet lambs exposed to one and two oral doses of Haemonchus contortus," American Journal of Veterinary Research, vol. 34, no. 6, pp. 729-735, 1973.

[32] M. Bahirathan, J. E. Miller, S. R. Barras, and M. T. Kearney, "Susceptibility of Suffolk and Gulf Coast Native suckling lambs to naturally acquired strongylate nematode infection," Veterinary Parasitology, vol. 65, no. 3-4, pp. 259-268, 1996.

[33] M. T. Gómez-Muñoz, M. Cuquerella, L. A. Gómez-Iglesias et al., "Serum antibody response of Castellana sheep to Haemonchus contortus infection and challenge: relationship to abomasal worm burdens," Veterinary Parasitology, vol. 81, no. 4, pp. 281-293, 1999.

[34] P. Díaz-Rivera, G. Torres-Hernández, G. M. Osorio-Arce et al., "Resistencia a parásitos gastrointestinales en ovinos Florida y Pelibuey y sus cruzas en el trópico mexicano," Agrociencia, vol. 34 , no. 1, pp. 13-20, 2000.

[35] M. Gauly and G. Erhardt, "Genetic resistance to gastrointestinal nematode parasites in Rhön sheep following natural infection," Veterinary Parasitology, vol. 102, no. 3, pp. 253-259, 2001.

[36] M. Gauly, M. Kraus, L. Vervelde, M. A. W. Van Leeuwen, and G. Erhardt, "Estimating genetic differences in natural resistance in Rhön and Merinoland sheep following experimental Haemonchus contortus infection," Veterinary Parasitology, vol. 106, no. 1, pp. 55-67, 2002.

[37] O. Matika, S. Nyoni, J. B. Van Wyk, G. J. Erasmus, and R. L. Baker, "Resistance of Sabi and Dorper ewes to gastro-intestinal nematode infections in an African semi-arid environment," Small Ruminant Research, vol. 47, no. 2, pp. 95-102, 2003.

[38] L. Gruner, G. Aumont, T. Getachew et al., "Experimental infection of Black Belly and INRA 401 straight and crossbred sheep with trichostrongyle nematode parasites," Veterinary Parasitology, vol. 116, no. 3, pp. 239-249, 2003.

[39] H. B. Vanimisetti, S. P. Greiner, A. M. Zajac, and D. R. Notter, "Performance of hair sheep composite breeds: resistance of lambs to Haemonchus contortus," Journal of Animal Science, vol. 82, no. 2, pp. 595-604, 2004.

[40] J. E. Miller, M. Bahirathan, S. L. Lemarie, F. G. Hembry, M. T. Kearney, and S. R. Barras, "Epidemiology of gastrointestinal 
nematode parasitism in Suffolk and Gulf Coast Native sheep with special emphasis on relative susceptibility to Haemonchus contortus infection," Veterinary Parasitology, vol. 74, no. 1, pp. 55-74, 1998.

[41] J. M. Burke and J. E. Miller, "Relative resistance of Dorper crossbred ewes to gastrointestinal nematode infection compared with St. Croix and Katahdin ewes in the southeastern United States," Veterinary Parasitology, vol. 109, no. 3-4, pp. 265-275, 2002.

[42] J. M. Burke and J. E. Miller, "Relative resistance to gastrointestinal nematode parasites in Dorper, Katahdin, and St. Croix lambs under conditions encountered in the southeastern region of the United States," Small Ruminant Research, vol. 54, no. 1-2, pp. 43-51, 2004.

[43] J. M. Mugambi, J. O. Audho, and R. L. Baker, "Evaluation of the phenotypic performance of a Red Maasai and Dorper double backcross resource population: natural pasture challenge with gastro-intestinal nematode parasites," Small Ruminant Research, vol. 56, no. 1-3, pp. 239-251, 2005.

[44] P. A. Bricarello, A. F. T. Amarante, R. A. Rocha et al., "Influence of dietary protein supply on resistance to experimental infections with Haemonchus contortus in Ile de France and Santa Ines lambs," Veterinary Parasitology, vol. 134, no. 1-2, pp. 99-109, 2005.

[45] A. F. T. Amarante, P. A. Bricarello, J. F. Huntley, L. P. Mazzolin, and J. C. Gomes, "Relationship of abomasal histology and parasite-specific immunoglobulin A with the resistance to Haemonchus contortus infection in three breeds of sheep," Veterinary Parasitology, vol. 128, no. 1-2, pp. 99-107, 2005.

[46] B. Good, J. P. Hanrahan, B. A. Crowley, and G. Mulcahy, “Texel sheep are more resistant to natural nematode challenge than Suffolk sheep based on faecal egg count and nematode burden," Veterinary Parasitology, vol. 136, no. 3-4, pp. 317-327, 2006.

[47] M. A. Muñoz-Guzmán, J. A. Cuéllar-Ordaz, A. G. ValdiviaAnda, J. A. Buendía-Jiménez, and F. Alba-Hurtado, "Correlation of parasitological and immunological parameters in sheep with high and low resistance to haemonchosis," Canadian Journal of Animal Science, vol. 86, no. 3, pp. 363-371, 2006.

[48] G. Terefe, C. Lacroux, F. Prévot et al., "Eosinophils in Haemonchus contortus-infected resistant and susceptible breeds of sheep: abomasal tissue recruitment and in vitro functional state," Veterinary Parasitology, vol. 165, no. 1-2, pp. 161-164, 2009.

[49] H. A. Saddiqi, Z. Iqbal, M. N. Khan et al., "Evaluation of three Pakistani sheep breeds for their natural resistance to artificial infection of Haemonchus contortus," Veterinary Parasitology, vol. 168, no. 1-2, pp. 141-145, 2010.

[50] K. P. Shakya, J. E. Miller, L. G. Lomax, and D. D. Burnett, "Evaluation of immune response to artificial infections of Haemonchus contortus in Gulf Coast Native compared with Suffolk lambs," Veterinary Parasitology, vol. 181, no. 2-4, pp. 239-247, 2011.

[51] R. A. Rocha, P. A. Bricarello, M. B. Silva et al., "Influence of protein supplementation during late pregnancy and lactation on the resistance of Santa Ines and Ile de France ewes to Haemonchus contortus," Veterinary Parasitology, vol. 181, no. 2-4, pp. 229-238, 2011.

[52] J. F. González, Á. Hernández, J. M. Molina et al., "Comparative experimental Haemonchus contortus infection of two sheep breeds native to the Canary Islands," Veterinary Parasitology, vol. 153, no. 3-4, pp. 374-378, 2008.
[53] H. A. Saddiqi, A. Jabbar, M. Sarwar et al., "Small ruminant resistance against gastrointestinal nematodes: a case of Haemonchus contortus," Parasitology Research, vol. 109, no. 6, pp. 1483-1500, 2011.

[54] E. N. T. Meeusen, A. Balic, and V. Bowles, "Cells, cytokines and other molecules associated with rejection of gastrointestinal nematode parasites," Veterinary Immunology and Immunopathology, vol. 108, no. 1-2, pp. 121-125, 2005.

[55] H. R. P. Miller, "Prospects for the immunological control of ruminant gastrointestinal nematodes: natural immunity, can it be harnessed?" International Journal for Parasitology, vol. 26, no. 8-9, pp. 801-811, 1996.

[56] E. N. T. Meeusen and A. Balic, "Do eosinophils have a role in the killing of helminth parasites?" Parasitology Today, vol. 16, no. 3, pp. 95-101, 2000.

[57] S. Reinhardt, I. Scott, and H. V. Simpson, "Neutrophil and eosinophil chemotactic factors in the excretory/secretory products of sheep abomasal nematode parasites-NCF and ECF in abomasal nematodes," Parasitology Research, vol. 109, no. 3, pp. 627-635, 2011.

[58] A. Balic, V. M. Bowles, and E. N. T. Meeusen, "Mechanisms of immunity to Haemonchus contortus infection in sheep," Parasite Immunology, vol. 24, no. 1, pp. 39-46, 2002.

[59] K. M. MacKinnon, J. L. Burton, A. M. Zajac, and D. R. Notter, "Microarray analysis reveals difference in gene expression profiles of hair and wool sheep infected with Haemonchus contortus," Veterinary Immunology and Immunopathology, vol. 130, no. 3-4, pp. 210-220, 2009.

[60] M. Kojima, H. Hosoda, Y. Date, M. Nakazato, H. Matsuo, and $\mathrm{K}$. Kangawa, "Ghrelin is a growth-hormone-releasing acylated peptide from stomach," Nature, vol. 402, no. 6762, pp. 656-660, 1999.

[61] A. M. Wren, C. J. Small, H. L. Ward et al., "The novel hypothalamic peptide ghrelin stimulates food intake and growth hormone secretion," Endocrinology, vol. 141, no. 11, pp. 4325-4328, 2000.

[62] M. Otero, R. Nogueiras, F. Lago, C. Dieguez, J. J. Gomez-Reino, and O. Gualillo, "Chronic inflammation modulates ghrelin levels in humans and rats," Rheumatology, vol. 43, no. 3, pp. 306-310, 2004.

[63] A. Ingham, M. Menzies, P. Hunt, A. Reverter, R. Windon, and N. Andronicos, "Divergent ghrelin expression patterns in sheep genetically resistant or susceptible to gastrointestinal nematodes," Veterinary Parasitology, vol. 181, no. 2-4, pp. 194-202, 2011.

[64] P. G. C. Douch, P. E. Morum, and B. Rabel, "Secretion of anti-parasite substances and leukotrienes from ovine gastrointestinal tissues and isolated mucosal mast cells," International Journal for Parasitology, vol. 26, no. 2, pp. 205-211, 1996.

[65] M. A. Hohenhaus and P. M. Outteridge, "The immunogenetics of resistance to Trichostrongylus colubriformis and Haemonchus contortus parasites in sheep," British Veterinary Journal, vol. 151, no. 2, pp. 119-140, 1995.

[66] M. A. Rainbird, D. Macmillan, and E. N. T. Meeusen, "Eosinophil-mediated killing of Haemonchus contortus larvae: effect of eosinophil activation and role of antibody, complement and interleukin-5," Parasite Immunology, vol. 20, no. 2, pp. 93-103, 1998.

[67] P. Dorchies, J. P. Bergeaud, N. Van Khanh, and S. Morand, "Reduced egg counts in mixed infections with Oestrus ovis and Haemonchus contortus: influence of eosinophils?" Parasitology Research, vol. 83, no. 7, pp. 727-730, 1997. 
[68] C. Cuenca-Verde, J. A. Buendía-Jiménez, G. Valdivia-Anda, J. A. Cuéllar-Ordaz, M. A. Muñoz-Guzmán, and F. Alba-Hurtado, "Decrease in establishment of Haemonchus contortus caused by inoculation of a Taenia hydatigena larvae vesicular concentrate," Veterinary Parasitology, vol. 177, no. 3-4, pp. 332-338, 2011.

[69] C. A. Behm and K. S. Ovington, "The role of eosinophils in parasitic helminth infections: insights from genetically modified mice," Parasitology Today, vol. 16, no. 5, pp. 202-209, 2000.

[70] M. A. Muñoz-Guzmán, Evaluación comparativa de la respuesta inmune contra Haemonchus contortus en razas ovinas de alta y baja susceptibilidad [Ph.D. thesis], Universidad Nacional Autónoma de México, 2007.

[71] V. M. Bowles, M. R. Brandon, and E. N. T. Meeusen, "Characterization of local antibody responses to the gastrointestinal parasite Haemonchus contortus," Immunology, vol. 84, no. 4, pp. 669-674, 1995.

[72] D. P. Knox, D. L. Redmond, G. F. Newlands, P. J. Skuce, D. Pettit, and W. D. Smith, "The nature and prospects for gut membrane proteins as vaccine candidates for Haemonchus contortus and other ruminant trichostrongyloids," International Journal for Parasitology, vol. 33, no. 11, pp. 1129-1137, 2003.

[73] W. D. Smith, J. A. Van Wyk, and M. F. Van Strijp, "Preliminary observations on the potential of gut membrane proteins of Haemonchus contortus as candidate vaccine antigens in sheep on naturally infected pasture," Veterinary Parasitology, vol. 98, no. 4, pp. 285-297, 2001.

[74] L. F. LeJambre, R. G. Windon, and W. D. Smith, "Vaccination against Haemonchus contortus: performance of native parasite gut membrane glycoproteins in Merino lambs grazing contaminated pasture," Veterinary Parasitology, vol. 153, no. 3-4, pp. 302-312, 2008

[75] E. Cachat, G. F. J. Newlands, S. E. Ekoja, H. McAllister, and W. D. Smith, "Attempts to immunize sheep against Haemonchus contortus using a cocktail of recombinant proteases derived from the protective antigen, H-gal-GP," Parasite Immunology, vol. 32, no. 6, pp. 414-419, 2010.

[76] S. E. Ekoja and W. D. Smith, "Antibodies from sheep immunized against Haemonchus contortus with $\mathrm{H}$-gal-GP inhibit the haemoglobinase activity of this protease complex," Parasite Immunology, vol. 32, no. 11-12, pp. 731-738, 2010.

[77] W. D. Smith and D. S. Zarlenga, "Developments and hurdles in generating vaccines for controlling helminth parasites of grazing ruminants," Veterinary Parasitology, vol. 139, no. 4, pp. 347-359, 2006.

[78] J. M. Molina, S. Martín, Y. I. Hernández, J. F. González, O. Ferrer, and A. Ruiz, "Immunoprotective effect of cysteine proteinase fractions from two Haemonchus contortus strains adapted to sheep and goats," Veterinary Parasitology, vol. 188, no. 1-2, pp. 53-59, 2012.

[79] H. D. F. H. Schallig, M. A. W. Van Leeuwen, B. E. Verstrepen, and A. W. C. A. Cornelissen, "Molecular characterization and expression of two putative protective excretory secretory proteins of Haemonchus contortus," Molecular and Biochemical Parasitology, vol. 88, no. 1-2, pp. 203-213, 1997.

[80] H. J. Jacobs, C. Wiltshire, K. Ashman, and E. N. T. Meeusen, "Vaccination against the gastrointestinal nematode, Haemonchus contortus, using a purified larval surface antigen," Vaccine, vol. 17, no. 4, pp. 362-368, 1999.

[81] G. B. L. Harrison, H. D. Pulford, E. E. Doolin, A. Pernthaner, C. B. Shoemaker, and W. R. Hein, "Antibodies to surface epitopes of the carbohydrate larval antigen CarLA are associated with passive protection in strongylid nematode challenge infections," Parasite Immunology, vol. 30, no. 11-12, pp. 577-584, 2008.

[82] P. M. Outteridge, L. Andersson, P. G. C. Douch et al., "The PCR typing of MHC-DRB genes in the sheep using primers for an intronic microsatellite: application to nematode parasite resistance," Immunology \& Cell Biology, vol. 74, no. 4, pp. 330-336, 1996.

[83] L. Vervelde, N. Bakker, F. N. J. Kooyman et al., "Vaccinationinduced protection of lambs against the parasitic nematode Haemonchus contortus correlates with high IgG antibody responses to the LDNF glycan antigen," Glycobiology, vol. 13, no. 11, pp. 795-804, 2003.

[84] U. M. Padigel, J. J. Lee, T. J. Nolan, G. A. Schad, and D. Abraham, "Eosinophils can function as antigen-presenting cells to induce primary and secondary immune responses to Strongyloides stercoralis," Infection and Immunity, vol. 74, no. 6, pp. 3232-3238, 2006.

[85] M. Martínez-Valladares, M. P. Vara-Del Río, M. A. Cruz-Rojo, and F. A. Rojo-Vázquez, "Genetic resistance to Teladorsagia circumcincta: IgA and parameters at slaughter in Churra sheep," Parasite Immunology, vol. 27, no. 6, pp. 213-218, 2005.

[86] A. Pernthaner, R. J. Shaw, M. M. McNeill, L. Morrison, and W. R. Hein, "Total and nematode-specific IgE responses in intestinal lymph of genetically resistant and susceptible sheep during infection with Trichostrongylus colubriformis," Veterinary Immunology and Immunopathology, vol. 104, no. 1-2, pp. 69-80, 2005.

[87] A. Pernthaner, S. A. Cole, L. Morrison, R. Green, R. J. Shaw, and W. R. Hein, "Cytokine and antibody subclass responses in the intestinal lymph of sheep during repeated experimental infections with the nematode parasite Trichostrongylus colubriformis," Veterinary Immunology and Immunopathology, vol. 114, no. 1-2, pp. 135-148, 2006.

[88] C. de la Chevrotière, J. C. Bambou, R. Arquet, P. Jacquiet, and N. Mandonnet, "Genetic analysis of the potential role of IgA and IgE responses against Haemonchus contortus in parasite resistance of Creole goats," Veterinary Parasitology, vol. 186, no. 3-4, pp. 337-343, 2011.

[89] I. Van Die, V. Gomord, F. N. J. Kooyman, T. K. Van Den Berg, R. D. Cummings, and L. Vervelde, "Core $\alpha 1 \rightarrow 3$-fucose is a common modification of $\mathrm{N}$-glycans in parasitic helminths and constitutes an important epitope for IgE from Haemonchus contortus infected sheep," FEBS Letters, vol. 463, no. 1-2, pp. 189-193, 1999.

[90] H. S. Gill, A. J. Husband, and D. L. Watson, "Localization of immunoglobulin-containing cells in the abomasum of sheep following infection with Haemonchus contortus," Veterinary Immunology and Immunopathology, vol. 31, no. 1-2, pp. 179-187, 1992.

[91] M. A. Muñoz-Guzmán, C. Cuenca-Verde, G. Valdivia-Anda, J. A. Cuéllar-Ordaz, and F. Alba-Hurtado, "Differential immune response between fundic and pyloric abomasal regions upon experimental ovine infection with Haemonchus contortus," Veterinary Parasitology, vol. 185, no. 2-4, pp. 175-180, 2012.

[92] H. S. Gill, "Cell-mediated immunity in merino lambs with genetic resistance to Haemonchus contortus," International Journal for Parasitology, vol. 24, no. 5, pp. 749-756, 1994.

[93] H. J. Jacobs, K. Ashman, and E. N. T. Meeusen, "Humoral and cellular responses following local immunization with a surface antigen of the gastrointestinal parasite Haemonchus contortus," Veterinary Immunology and Immunopathology, vol. 48, no. 3-4, pp. 323-332, 1995. 
[94] H. S. Gill, D. L. Watson, and M. R. Brandon, "Monoclonal antibody to CD4+ $\mathrm{T}$ cells abrogates genetic resistance to Haemonchus contortus in sheep," Immunology, vol. 78, no. 1, pp. 43-49, 1993.

[95] F. N. Karanu, T. C. McGuire, W. C. Davis, T. E. Besser, and D. P. Jasmer, "CD4+ T lymphocytes contribute to protective immunity induced in sheep and goats by Haemonchus contortus gut antigens," Parasite Immunology, vol. 19, no. 10, pp. 435-445, 1997.

[96] M. T. Peña, J. E. Miller, and D. W. Horohov, "Effect of CD4+ T lymphocyte depletion on resistance of Gulf Coast Native lambs to Haemonchus contortus infection," Veterinary Parasitology, vol. 138, no. 3-4, pp. 240-246, 2006.

[97] I. R. Tizard, Introducción a la Inmunología Veterinaria, Elsevier, Barcelona, España, 8th edition, 2009.

[98] H. S. Gill, K. Altmann, M. L. Cross, and A. J. Husband, "Induction of $\mathrm{T}$ helper 1 - and $\mathrm{T}$ helper 2-type immune responses during Haemonchus contortus infection in sheep," Immunology, vol. 99, no. 3, pp. 458-463, 2000.

[99] A. Pernthaner, S. A. Cole, L. Morrison, and W. R. Hein, "Increased expression of interleukin-5 (IL-5), IL-13, and tumor necrosis factor alpha genes in intestinal lymph cells of sheep selected for enhanced resistance to nematodes during infection with Trichostrongylus colubriformis," Infection and Immunity, vol. 73, no. 4, pp. 2175-2183, 2005.

[100] N. Andronicos, P. Hunt, and R. Windon, "Expression of genes in gastrointestinal and lymphatic tissues during parasite infection in sheep genetically resistant or susceptible to Trichostrongylus colubriformis and Haemonchus contortus," International Journal for Parasitology, vol. 40, no. 4, pp. 417-429, 2010.

[101] L. J. Cliffe, N. E. Humphreys, T. E. Lane, C. S. Potten, C. Booth, and R. K. Grencis, "Accelerated intestinal epithelial cell turnover: a new mechanism of parasite expulsion," Science, vol. 308, no. 5727, pp. 1463-1465, 2005.

[102] D. L. Watson, I. G. Colditz, M. Andrew, H. S. Gill, and K. G. Altmann, "Age-dependent immune response in Merino sheep," Research in Veterinary Science, vol. 57, no. 2, pp. 152-158, 1994.

[103] C. R. Mackay and W. R. Hein, "Marked variations in $\gamma \delta$ T cell numbers and distribution throughout the life of sheep," Current Topics in Microbiology and Immunology, vol. 173, pp. 107-111, 1991.

[104] P. R. Wood and H. F. Seow, "T cell cytokines and disease prevention," Veterinary Immunology and Immunopathology, vol. 54, no. 1-4, pp. 33-44, 1996. 

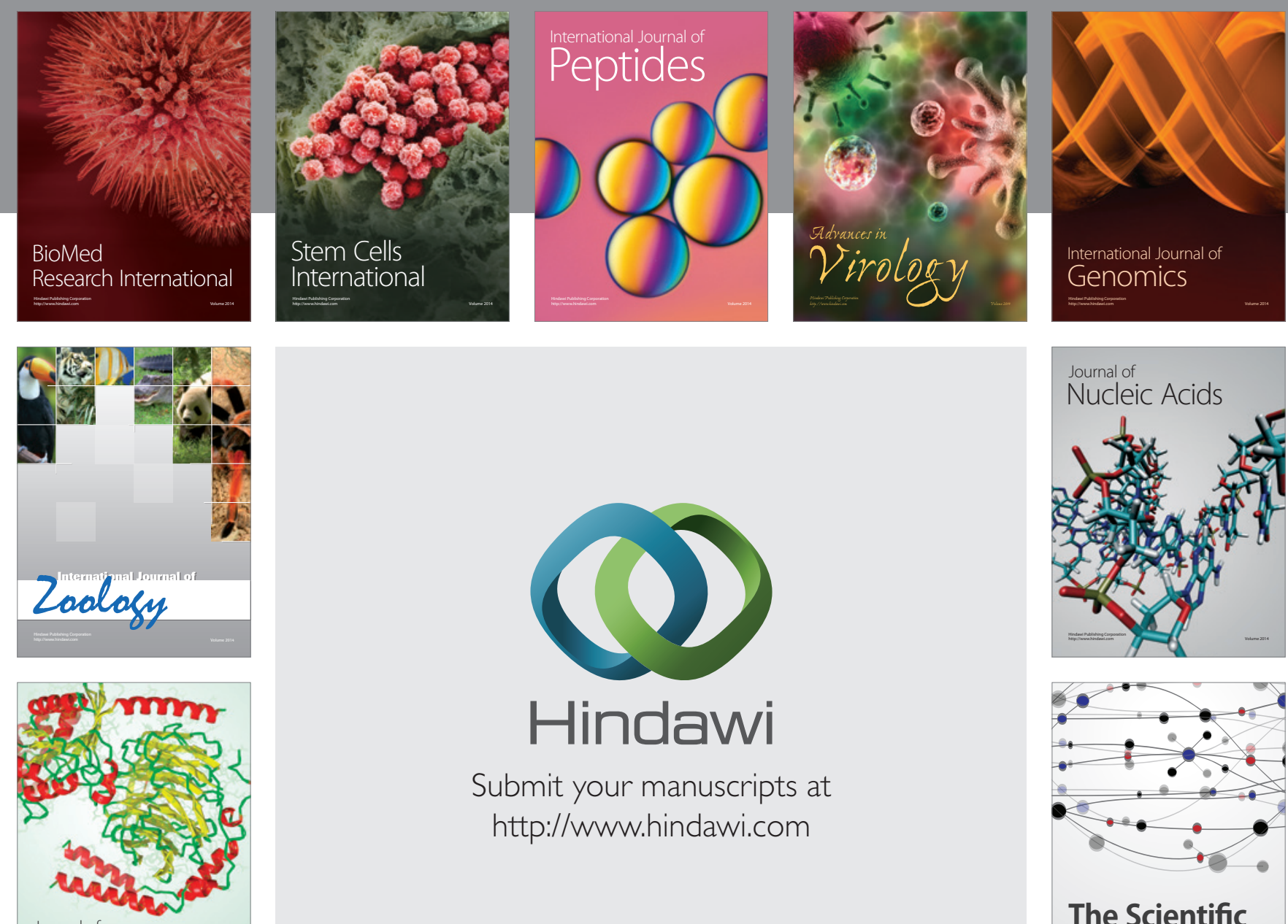

Submit your manuscripts at

http://www.hindawi.com

Journal of
Signal Transduction
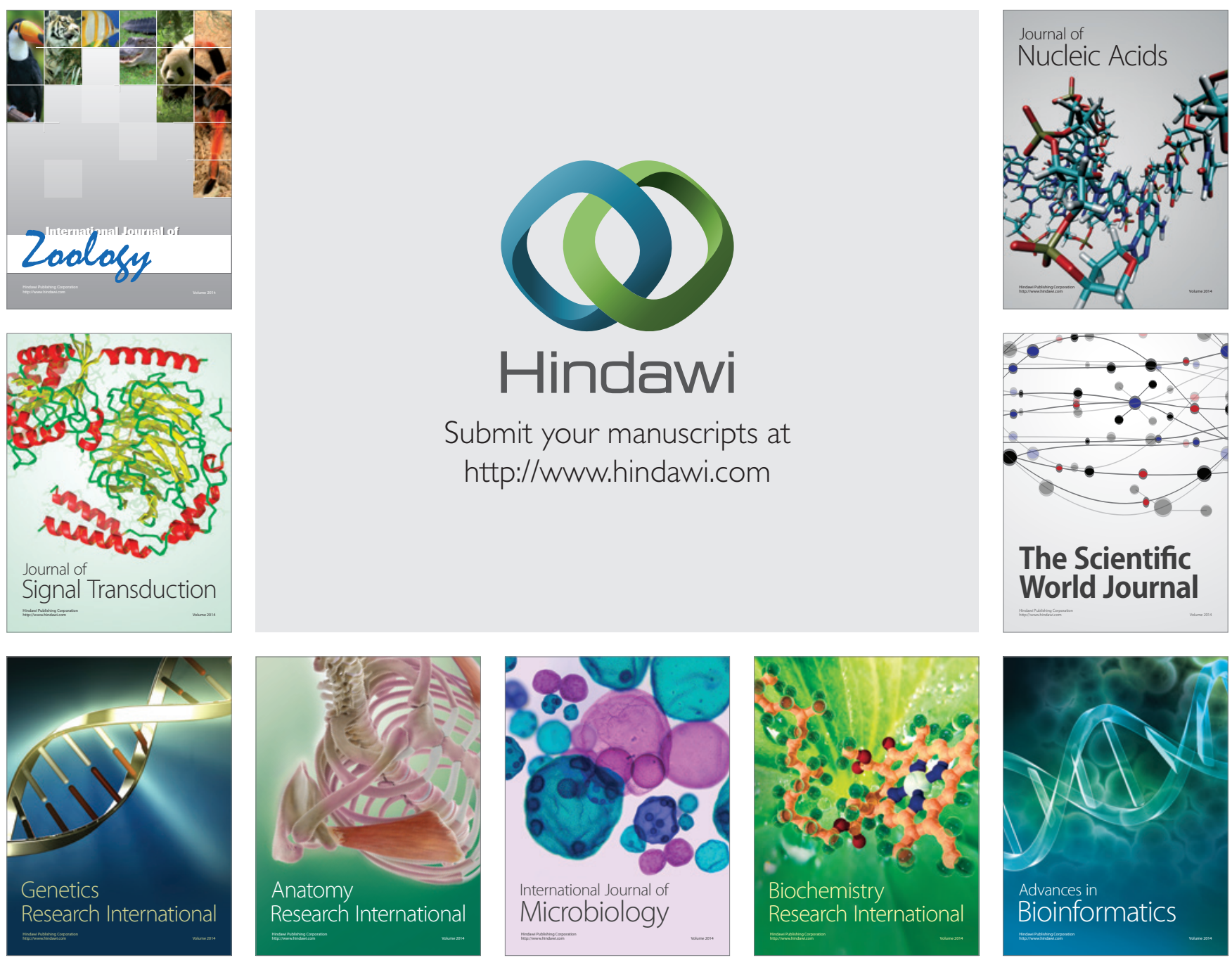

The Scientific World Journal
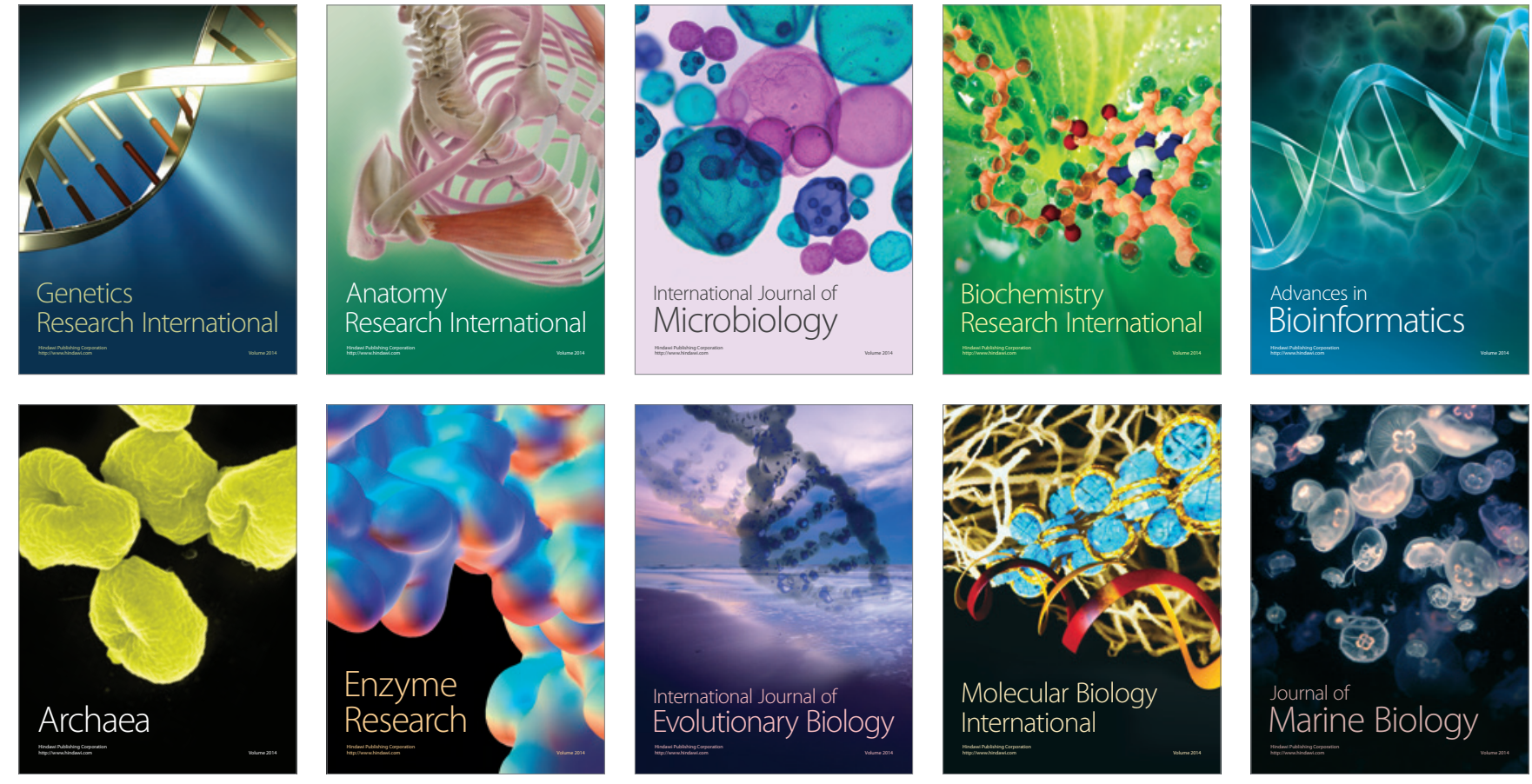